\section{Geographic Influence on Innovation and Entrepreneurship Spillovers}

\author{
Mohamed Buheji (Corresponding Author) \\ Founder of the International Inspiration Economy Project - Bahrain \\ E-mail: buhejim@gmail.com
}

Received: January 12, 20120 Accepted: February 23, $20120 \quad$ Published: March 16, 20120

doi:10.5296/rbm.v7i2.16677 URL: http://dx.doi.org/10.5296/rbm.v7i2.16677

\begin{abstract}
This paper critically reviews the role of geography and location on the spread and the quality of innovation and entrepreneurship. Since innovation is highly related to geographic competition, sources of geographic advantage are reviewed with a focus on the work of Gråsjö et al. (2018).

The research defines the requirement for shifting towards innovation geographic concentration and how it might lead to both resilient economies that benefit from the spillovers. The paper concludes with recommendations on building future strategies based on the foresighted future spillovers.
\end{abstract}

Keywords: Geographic influence on Innovation, Open Innovation, Entrepreneurship, Economic Spillover, Resilience Economy, Future Foresight.

\section{Introduction}

This paper explores how innovation and entrepreneurship to help organisations, communities and countries compete through benefiting from spillovers and their related proximities.

Geography provides a range of highlights that need to be investigated in relevance to innovation and entrepreneurship. The critical literature review targets to provide the policy planners and consultants with more source of economic development differentiation.

\section{Critical Literature Review}

Aspects of open innovation and entrepreneurship are not well addressed in the literature. Open innovation brings in more practices as sharing economy, or collaborative economy. Such practices enhance the competitiveness of SME's competitiveness. Porter and Stern (2001).

Open innovation is usually influenced by public infrastructure. Therefore, Gråsjö et al. (2018) show the importance of the role of the Canadian government on the adoption of open innovation. The Gråsjö team showed how innovative sectors as the Canadian Nanotechnology, 
and its Aerospace industry could influence the innovation spillover due to proximity bias.

Open innovation creates the possibility of more spillover that could come from re-conceptualising entrepreneurial ecosystems. Then the importance of having cross-border clusters. Stam (2010).

\subsection{Geography and Innovation}

Integration of innovation with specific geography brought in differentiation for certain development for specific regions, such as the cities near the California's Silicon Valley. Such geography made the forefront of innovation. Porter and Stern (2001).

Geographic locations leverage capital resources besides optimising the benefit of regional connections. Benefiting from this would lead developing economies towards significant regional innovation that have tolerant resilient economy. Buheji (2018).

Over the past two decades, we started to witness a shift in innovation in many regions in the world. For example, the geographic concentration shows a higher concentration of innovations in South East Asia and Far East Asia, while the same time we started to see the enlargement of geographic inequality in wealth and capacity for job creation. Howells and Bessant (2012).

\subsection{Geography and Entrepreneurship}

Entrepreneurship is fundamental for economic development. Reaching-out to entrepreneurial opportunities can alter the economic environment by creating more alternatives observation of sources of wealth that bring in market niches from different communities. Stam (2010).

Opportunities provide the community with new entrepreneurs that can build on each other and smoothen the journey of entrepreneurship turbulence. One entrepreneur is a source for at least two other entrepreneurship opportunities. Motoyama and Danley (2012).

Entrepreneurship has always been seen as a product of its environment, besides personal characteristics. The entrepreneurial opportunities identify and exploit new products and services development, and establish clusters for financing the projects. In most economic geography models, innovation and growth depend on clusters that realise the microeconomics. Howells and Bessant (2012).

\subsection{Innovation and Geographic Competition}

More than ever today, companies are being able to innovate at the global frontier due to their geographic advantage. These companies can create and commercialise new products and or services that create traditional thinking about the management of innovation. Porter and Stern (2001).

Motoyama and Danley (2012) how regional characteristics are associated with fast-growing companies and innovations. Motoyama and Danley analysed the innovations in regions that continuously produce fast-growing companies. Certain countries have managed to put an attractive environment for innovation and entrepreneurship patterns. These countries managed to establish a cluster-specific environment that commercialised innovations. Stam 
(2010).

Motoyama and Danley (2012) found that the innovations and growth of firms that are influenced by their geography come from a wide range of industries. Studies show that IT (19.4 per cent), Health and Drugs (6.5 per cent), Business Services (10.2 per cent), Advertising and Marketing (8.5 per cent), and Government Services (7.3 per cent).

\subsection{Sources of Geographic Advantage}

Based on the review from the literature, one could conclude that the regional development brings in more opportunities for the presence of venture capital investments, high-quality research universities, proper research and development programs which lead to more patents and differentiation in market disruption capability. This brings in the higher possibility for the concentration of a highly skilled labour force in the neighbouring regions.

Most economists agree that fast-growth startups create the bulk of the nation's new jobs. They are the source for "creative destruction" and sources of entrepreneurial economic development. However, Gråsjö et al. (2018) defined more specific locational factors that lead to differentiated competitiveness of any country and community, when benefiting from a locational advantage. The top of these influences starts with the increase in the quantity and quality of skilled labour, especially with the increase of demanding customers. The availability of supporting industries in the same region helps to differentiate the competitiveness of the regional actors.

\subsection{Influence of Proximity and Learning for Future Competitiveness}

Boschma (2005) emphasised more studies are needed in the types of proximity influence. Many countries could differentiate their competitiveness today and, in the future, based on the type and the extent of geographical proximity, cognitive proximity, organisational proximity, social proximity, besides technical proximity.

The geographical proximity creates more impact on interactive learning and innovation, Buheji and Ahmed (2019). This type of proximity provides alternative solutions and potential developments that facilitates interactive learning by ensuring openness and flexibility. The geographical proximity brings in organisational proximity which creates interactive learning where relations shared creates a rate of autonomy and a degree of control that can be exerted on the development of the region. Boschma (2005).

When knowledge is produced as a public good inside the economic system, cognitive proximity occurs, and develops better communication. The novelty of sources triggers new ideas and brings in creativity to all the region's organisations. This brings social proximity which builds relations that affect economic outcomes that lead socially embedded relations that facilitate the exchange of innovation and entrepreneurial tacit knowledge. Buheji and Ahmed (2019).

\subsection{Foresighting Potential Future Geographic Spillovers}

Geographically, both innovation and entrepreneurship create positive spillovers that lead to structuration which establish all the type of enablers and differentiation actors. This can be 
seen clearly today in the demanding tech industry, besides the ecosystems entrepreneurship start-ups. Motoyama and Danley (2012).

The proximity bias of the geographic spillovers is leading today to more innovative openness and the adoption of new creative approaches, Boschma (2005). Through public-private partnership (PPP), more suitable incentives can be provided depending on the targeted sector. Many countries today started to build a capacity on how to foresight for more FDI spillovers could be established based on the geographic dimension.

\section{Discussion and Concluding Remarks}

This paper analyses the effects of geographical and locational factors that differentiates any country innovation and entrepreneurial competitiveness.

This work benefits from the main reference used in this study, i.e. Gråsjö et al. (2018), in establishing clusters based on strong relationships between local and regional competitions that lead to evolving innovation.

The limitations of Gråsjö et al. (2018) in addressing the spillovers created by the inter-organisational networking does not hinder the uniqueness of this book from being considered as one of the main references in defining the geographic advantage in shaping the innovative activity that stimulates more collaborative innovation projects.

More studies are recommended in the investigation of the spillovers that could be captured due to localised inter-organizational demands that build the know-how and the innovative local environment. It is, therefore, highly recommended that future innovation and entrepreneurial strategies should be built based on the foresighted future spillovers that come from the different proximities that the geographic advantage creates.

\section{References}

Boschma, R. (2005). Proximity and innovation: a critical assessment. Regional studies, 39(1), 61-74.

Buheji, M. (2018). Understanding the power of resilience economy: An inter-disciplinary perspective to change the world attitude to socio-economic crisis. Mohamed Buheji.

Buheji, M., \& Ahmed, D. (2019). Reviewing How Capitalism is Destroying Itself? Technology Displaced by Financial Innovation. American Journal of Economics, 9(5), 264-267.

Gråsjö, U., Karlsson, C., \& Bernhard, I. (2018). Geography, open innovation and entrepreneurship Cheltenham. E-Elgar Publishing, UK.

Howells, J., \& Bessant, J. (2012). Introduction: innovation and economic geography: a review and analysis. Journal of economic geography, 12(5), 929-942.

Motoyama, Y., \& Danley, B. (2012). The ascent of America's high-growth companies. Kauffman Research Paper Series. Kansas City, MO: Kauffman Foundation. 
Porter, M. E., \& Stern, S. (2001). Innovation: location matters. MIT Sloan management review, 42(4), 28.

Stam, E. (2010) Entrepreneurship and Geography: An Evolutionary Perspective. Paper for the 13th Uddevalla Symposium 2010 Special Session Innovation and Multidimensional Entrepreneurship - Economic, Social and Academic Aspects. Retrieved from https://www.academia.edu/2788779/Entrepreneurship_and_Geography_An_Evolution ary_Perspective

\section{Copyright Disclaimer}

Copyright reserved by the author(s).

This article is an open-access article distributed under the terms and conditions of the Creative Commons Attribution license (http://creativecommons.org/licenses/by/3.0/). 